\title{
ОСНОВНИЙ КОРМ 3 ГІБРИДНОГО ОЗИМОГО ЖИТА: ЗАГОТІВЛЯ, ЯКІСТЬ ТА ВИКОРИСТАННЯ У ГОДІВЛІ МОЛОЧНИХ КОРІВ
}

\author{
Шевчук Олег Антонович \\ директор ПП «Слободище» Бердичівського району \\ Житомирської області \\ ORCID: 0000-0002-3781-945 \\ E-mail: slobodysche2005@ukr.net
}

Ковальчук Ігор Васильович кандидат сільськогосподарських наук, доцент Поліський національний університет ORCID: 0000-0002-5775-4140 E-mail: ikovalchuk_08@ukr.net

Шиян Микола Олександрович
зоотехнік ПП «Слободище» Бердичівського району
Житомирської області
ORCID: 0000-0002-3781-945
E-mail: slobodysche2005@ukr.net

Ковальчук Ірина Ігорівна кандидат ветеринарних наук, старший викладач Поліський національний університет ORCID: 0000-0002-2421-7533

E-mail: kovalchuk_ira0982@ukr.net

Основним чинником зниження молочної продуктивності корів, тривалості їх господарського використання, репродуктивної функиії є прямий вплив низки аліментарних факторів. Саме тому, в останні роки менеджмент молочних ферм спрямовуе свою роботу на проведення оцінки якісних характеристик основних кормів (сіна, силосу, сінажу) для годівлі великої рогатої худоби. Варто зазначити, що нині прослідковується тенденція до застосування у практиці кормів, зокрема силосу, із злакових культур. Перспективним $є$ виготовлення такого корму із озимого жита, завдяки його невибагливості до агротехніки (морозостійкість, ранній посів, інтенсивний розвиток), високій урожайності, стійкості до грибкових захворювань. Крім того, житній силос характеризується високим вмістом поживних речовин. Саме тому, основним завданням наших досліджень було вивчити систему заготівлі та провести оцінку еффективності використання як основного корму силосу із озимого жита у годівлі високопродуктивних молочних корів в умовах ПП «Слободище» Бердичівського району Житомирської області. Мета роботи полягала у вивченні впливу загально змішаного раціону різного складу на молочну продуктивність корів. Нами подана технологічна схема із агротехніки гібридного озимого жита, заготівлі та приготування силосу. Встановлено, що за основними якісними показниками силос із гібридного озимого жита відповідає вимогам 1 класу (згідно ДСТУ 4782:2007). Для виконання виробничого досліду було залучено 520 голів корів голштинської і джерсейської порід. Тривалість досліду - 60 діб із поділом на два періоди: 1-й - використання силосу кукурудзяного, як основного корму (попереднього року заготівлі), 2-й - застосування силосу кукурудзяного та раннього силосу із озимого жита. З'ясували, що при годівлі корів силосом із озимого жита, - як основного корму, разом із кукурудзяним валове виробництво молока зросло на 197,86 и, а в перерахунку на 4 \% молоко на 131,43 и, підвищилися середньодобові надої на 1 корову (+1,3; +0,89 кг) відповідно, тому його використання у вигляді основного корму є иілком обгрунтованим з огляду на менеджмент годівлі дійного стада та економічні показники виробництва молока.

Ключові слова: озиме жито, технологічні операції, силос, годівля корів, основний корм, кетоз, високомолочна худоба, надій.

DOI: https://doi.org/10.32845/bsnau.lvst.2021.2.23

Сучасні стада молочної худоби характеризуються досить високим рівнем надоїв, що вимагає балансування раціонів за рівнем енергетичного і протеїнового живлення з використанням значної кількості концентрованих кормів, що призводить до таких проблем як ацидоз та кетоз, а порушення менеджменту годівлі корів - основний чинник зниження молочної продуктивності корів, тривалості їх використання, репродуктивних якостей внаслідок дії аліментарних факторів.

Кількість споживання корму залежить на 40-60 \% від

індивідуальних особливостей тварини - жива маса, стан здоров'я, вік, стадія лактації, тільності; 20-30 \% - корму (склад і поживна цінність); 10-15 \% - утримання; 10-15\% організації і техніки годівлі, що обумовлюють споживання сухої речовини від 3 до 3,5 \% живої маси тварини. Вільний доступ до кормового столу повинен забезпечуватися худобі протягом 20 годин на добу [2, 5].

Тому, все частіше, для забезпечення рівня повноцінної годівлі, значна увага надається якості основних кормів - сіна, силосу, сінажу з огляду на ряд викликів, які 
постали перед спеціалістами у галузі кормовиробництва та молочного скотарства: зростання вартості зерна, зміна клімату, загальне збільшення виробничих витрат на утримання поголів'я тощо.

Ведення галузі молочного скотарства, його рентабельність, покращення якості отримуваної продукції та зниження її собівартості пов'язані, насамперед, із повноцінною годівлею корів. Якість силосованих кормів $є$ провідним фактором їх використання у складі раціону і, як наслідок, розкриття генетичного потенціалу худоби [12]. J. A. Paterson 3 співавторами зазначає, що основним завданням при вирощуванні великої рогатої худоби повинно бути забезпечення господарства кормами, які б покривали бажаний рівень приросту і виробництва молока, адже висока продуктивність жуйних тварин є найвищим показником якості кормів [14]. При цьому оптимальний рівень виробництва високоякісного молока досягається за умови збалансованості раціону, які задовольняють організм тварин повним спектром поживних речовин, саме тому варто відслідковувати поживну цінність кормів і за потреби доповнювати раціон мінералами, вітамінами та добавками [13].

Останнім часом в годівлі молочних кормів набуває поширення тенденція застосування нового покоління кормів - силосу із цільних культур. Його можна заготовити як 3 озимих, так і ярових злакових культур - вівса, ячменю, пшениці, тритикале, жита. Зрозуміло, що агротехніка цих культур відрізняється, але спільним у технології заготівлі корму є силосування рослин у фазі «прапорцевого листка», дотримання висоти зрізу для уникнення значної контамінації маси ґрунтом, пров'ялювання - для збільшення вмісту сухої речовини [1].

Особливо перспективним для приготування такого корму $€$ озиме жито - завдяки його високій урожайності стійкості до грибкових захворювань, невибагливості до ґрунтів. При цьому слід пам'ятати, що найважливішим фактором, який буде визначати якість та поживність корму $є$ оптимальний час скошування [4, 8].

Для озимого жита характерним $€$ ранні терміни посіву, морозостійкість, інтенсивний весняний розвиток, короткий весняний період вегетації до скошування [10].

Рослини, які скошені на ранніх стадіях мають більшу поживність, але й містять більше вологи, тому таке жито слід прив'ялювати, але при цьому максимально унеможливити забруднення його ґрунтом - це сприяє погіршенню бродильних процесів [6]. Крім того є ризик зараження клостридіями та іншими спороутворюючими мікроорганізмами, які в подальшому можуть контамінувати молоко [11]

За даними багатьох досліджень житній силос (сінаж) характеризується високим вмістом енергії, протеїну, перетравної клітковини, добре споживається і легко перетравлюється худобою, що робить його перспективним для годівлі у літні спекотні періоди [3, 9].

Крім того використання озимого жита має і ряд економічних переваг: низьку собівартість (близько 700 грн/т) в умовах України [7]. А також можливість раціонально використовувати ріллю, оскільки у якості поукісної культури застовують кукурудзу на зелений корм [15].

Тому оцінка ефективності використання у якості основного корму силосу із озимого жита у годівлі високопродуктивних молочних корів $€$ актуальним завданням.

Вивчення впливу загально змішаного раціону різного складу на молочну продуктивність корів в умовах ПП «Слободище» Бердичівського району Житомирської області стало метою роботи.

Завдання досліджень - вивчити систему організації заготівлі основного корму із озимого жита з оцінкою його поживності та використання у раціонах годівлі молочних корів.

Методика і матеріали досліджень. Матеріалом для досліджень слугували технологічна карта вирощування і заготівлі раннього силосу із озимого жита, середні проби корму, дані виробничого зоотехнічного обліку. Відбір середніх проб корму для оцінки поживності здійснювався за загальноприйнятими методами. Ефективність використання раннього силосу у загально змішаному раціоні вивчалась у виробничому досліді на 520 коровах голштинської і джерсейської порід.

Результати досліджень. Спеціалізація ПП «Слободище» - виробництво молока. Дійне стадо складається 3 корів голштинської та джерсейської порід. На перспективу планується збільшення поголів'я корів до 2000. Тому відпрацювання технології заготівлі і забезпечення основним кормом дійного стада досить актуальне завдання. 3 цією метою, з врахуванням досвіду низки господарств України, фахівці підприємства прийняли рішення застосувати озиме жито для заготівлі раннього силосу.

У якості посівного матеріалу використовували гібридні сорти жита озимого. Площа посіву склала 130 га. Обробіток ґрунту включав: оранка на глибину 25-27 см або дискування залежно від попередника (люцерни чи кукурудзи); передпосівної культивації; посіву на глибину 2-3 см, протруєним насінням (норма висіву 2,3 млн шт/га). При посіві, у якості добрива вносили аміачну селітру (100 кг/га у фізичній вазі).

Весняне підживлення проведене КАС-32. Укіс на ранній силос розпочали у фазі «прапорцевого листка», при середній висоті рослин 50-60 см та висоті зрізу - 10-13 см.

При цьому застосовували наступні технологічні операції: скошування - роторними косарками, формування валків - валкоутворювачами, подрібнення та завантаження зеленої маси - кормозбиральними комбайнами Ягуар-240. Довжина різки складала 3-4 см. Транспортування здійснювалось вантажними автомобілями КАМАЗ, тракторними причепами.

Трамбування сировини проводили трактором К-700, обладнаним додатковим вантажем та відвалом, що збільшило його масу до 13,4 тонн, консервацію маси виконували багатокомпонентним консервантом «Бактосил» з розрахунку - 1 г/т маси. Укриття траншей - плівочне із фіксуванням вживаними шинами, мішками з піском.

Всього було закладено 1100 тонн сінажу.

Аналіз поживної цінності сінажу із озимого жита був проведений у виробничо-технологічній лабораторії ТОВ «НВП «Укрзооветпромпостач» (Київська область, Макарівський р-н, с. Плахтянка). За результатами досліджень вміст сухої речовини у сінажі склав 28,3 \%, рівень рН 4,0, масова частка молочної кислоти - $2,6 \%$, оцтової - 0,62 \%, масляна - відсутня. Масова частка сирого протеїну в сухій речовині становила 16,57 \%, сирої клітковини 29,63, сирої золи 14,73, НДК - 54,32, КДК - 29,62, а в натуральному кормі - 4,63 \%, 8,39, 4,17, 15,38, 8,39 \% відповідно.

Отже, ранній силос із озимого жита за показниками 
поживності відповідає вимогам 1 класу (ДСТУ 4782:2007) за винятком показника зольності.

Таким чином, для годівлі молочної худоби отримано основний корм, який має високий вміст енергії, добру перетравність та достатній рівень протеїну і $€$ потужним інструментом балансування раціонів корів. Це високоякісний корм за технологією виробництва сінажу, однак ферментативні процеси консервування проходять за принципом силосування. Сінаж з гібридного озимого жита є цінним серед використовуваних в скотарстві кормів та може збільшити молочну продуктивність корів.

При його заготівлі необхідно використовувати гібридні сорти озимого жита, скошувати у фазі «прапорцевого листка» на висоті 10-12 см для зменшення золи в кормі, дотримуватись термінів збирання та техніки трамбування зеленої маси.

Для оцінки ефрективності згодовування раннього силосу із озимого жита із застосуванням консерванту «Бактосил» нами був проведений виробничий дослід методом періодів на дійному поголів"ї корів джерсейської (120 голів) і голштинської (400 голів) корів 1-2 лактації.

Дослід тривав 60 діб із поділом на два періоди: 30 днів - у червні при застосуванні у якості основного корму силосу кукурудзяного (надходження попереднього року заготівлі) та 30 днів у липні місяці при використанні такого ж силосу кукурудзяного та раннього силосу із озимого жита.

Для аналізу продуктивності використали дані виробничої звітності.

За сухою речовиною у структурі раціону об'ємисті корми становили $65 \%$, концентровані - $31 \%$.

При заміні силосу кукурудзяного за енергетичною поживністю на силос житній вміст сирого протеїну в раціоні збільшився на 660 г, перетравного - 486 г, на 1 кг сухої речовини у другому періоді досліду припадало 156 г сирого протеїну та 119 г перетравного, а в першому відповідно 148 та 114 г.

Кількість клітковини в сухій речовині становила $17 \%$, що є оптимальним для корів середини лактації.

Що стосується вмісту жиру, цукру, крохмалю в сухій речовині, співвідношення Са : Р, то воно було в межах норми протягом періодів досліду (таблиця 1).

Таблиця 1.

Раціони дійних корів живою масою 600 кг, середньодобовим надоєм 30 л при проведенні виробничого досліду

\begin{tabular}{|c|c|c|}
\hline \multirow{2}{*}{ Показник } & \multicolumn{2}{|c|}{ Період досліду } \\
\hline & I (червень) & II (липень) \\
\hline \multicolumn{3}{|l|}{ Склад раціону, кг: } \\
\hline солома ячмінна & 2 & 0,5 \\
\hline силос житній & - & 23,0 \\
\hline силос кукурудзяний & 27 & 14,0 \\
\hline корнаж кукурудзяний (паста) & 4 & 7,0 \\
\hline макуха соєва & 2,7 & 3,0 \\
\hline шрот соєвий & - & 0,75 \\
\hline шрот соняшниковий & 2,75 & 1,0 \\
\hline жом & 8 & 9,0 \\
\hline сіль кухонна & 0,08 & 0,09 \\
\hline вапняне борошно & 0,100 & 0,120 \\
\hline сода харчова & 0,08 & 0,140 \\
\hline премікс «Зоовіт-Молочна корівка - 3 \%» & 0,200 & 0,200 \\
\hline \multicolumn{3}{|l|}{ У раціоні міститься: } \\
\hline Обмінної енергії ВРХ, мДЖ & 193,53 & 255,86 \\
\hline Чистої енергії ВРХ, мДЖ & 134,11 & 163,93 \\
\hline Суха речовина, кг & 20,02 & 23,23 \\
\hline Сирий протеїн, г & 2981,2 & 3641,25 \\
\hline Перетравний протеїн, г & 2289,17 & 2775,65 \\
\hline Розщеплюваний протеїн, г & 2028,5 & 2540,75 \\
\hline Нерозщеплюваний протеїн, г & 1042,9 & 1402,95 \\
\hline Сирий жир, г & 630,4 & 802,45 \\
\hline Сира клітковина, г & 3443,8 & 4070,90 \\
\hline Структурна клітковина, г & 2159,6 & 2810,25 \\
\hline КДК, г & 3740,5 & 4609,7 \\
\hline НДК, г & 6934,6 & 7995,75 \\
\hline Крохмаль, г & 6370,6 & 5030,55 \\
\hline Цукор, г & 441,01 & 525,28 \\
\hline Баланс азоту рубця & 4,28 & 47,57 \\
\hline OE врх / C.P. & 9,67 & 11,01 \\
\hline CП/ C.P. & 148,91 & 156,75 \\
\hline CK/C.P. & 171,97 & 175,24 \\
\hline КДК /C. Р. & 186,84 & 198,44 \\
\hline НДК / С. Р. & 346,38 & 344,20 \\
\hline Цукор / протеїн перетравний & 0,19 & 0,19 \\
\hline $\mathrm{Ca} / \mathrm{P}$ & 1,89 & 1,64 \\
\hline $\mathrm{P} \Pi /$ C.P. & 0,68 & 0,70 \\
\hline Сирий жир / C.P. & 31,49 & 34,54 \\
\hline
\end{tabular}


Застосування у годівлі молочних корів силосноконцентратних раціонів обумовлює надходження і утворення у рубці значної кількості органічних кислот, які підвищують кислотність рубця. Для його підтримання в межах норми до складу раціону входить харчова сода у кількості 80-140 г на голову/добу.

В першому періоді досліду корови отримували із си- лосом 648 г органічних кислот.

Їх надходження у другому періоді ставило 472 г, що обумовило краще споживання корму, засвоєння його поживних речовин і, як наслідок, вищі надої.

Аналіз показників молочної продуктивності корів при згодовуванні в якості основних кормів силосу кукурудзяного та силосу із озимого жита поданий у таблиці 2.

Таблиця 2

Продуктивність піддослідних корів

\begin{tabular}{|c|c|c|c|}
\hline \multirow{4}{*}{ Показники } & \multicolumn{2}{|c|}{ Період досліду } & \multirow{4}{*}{$\begin{array}{l} \pm \text { другий період } \\
\text { до першого }\end{array}$} \\
\hline & I (червень) & II (липень) & \\
\hline & \multicolumn{2}{|c|}{ Кількість дійних корів, гол } & \\
\hline & 520 & 520 & \\
\hline Валовий надій натурального молока, ц & 4546,71 & 4744,57 & $+197,86$ \\
\hline Середньодобовий надій натурального молока, кг & 28,1 & 29,4 & $+1,3$ \\
\hline Середній вміст жиру в молоці, \% & 3,92 & 3,83 & $-0,09$ \\
\hline Валовий надій молока в перерахунку на 4 \% жирність, кг & 4492,15 & 4623,58 & $+131,43$ \\
\hline Середньодобовий надій молока в перерахунку на 4 \% жирність, кГ & 27,76 & 28,65 & $+0,89$ \\
\hline \multicolumn{4}{|l|}{ Витрати корму на 1 кг молока, мДж ОЕ: } \\
\hline натуральної жирності & 6,89 & 8,7 & $+1,81$ \\
\hline 4 \% жирності & 6,97 & 8,93 & $+1,96$ \\
\hline Вартість 1кг СР, грн & 6,00 & 7,17 & $+1,17$ \\
\hline
\end{tabular}

При згодовуванні у якості основного корму силосу із озимого жита разом із кукурудзяним валове виробництво молока зросло на 197,86 ц, а в перерахунку на 4 \% молоко на 131,43 ц, підвищилися середньодобові надої на 1 корову відповідно +1,3; +0,89 кг.

Отже, використання у якості основного корму силосу із озимого жита $€$ цілком обґрунтованим технологічним прийомом з огляду на менеджмент годівлі дійного стада та економічні показники виробництва молока.

Висновки. 1. Основний корм для годівлі молочних корів силос житній та кукурудзяний відповідають добрій якості за показниками вмісту поживних речовин завдяки дотриманню технології заготівлі у відповідності до ДСТУ
4782:2007.

2. Господарські раціони годівлі молочної худоби відповідають критеріям за обмінною енергією, сирим протеїном, сирою клітковиною, сирим жиром, вологістю корму та вмістом сухої речовини.

3. При згодовуванні як основного корму силосу із гібридного озимого жита разом із кукурудзяним валове виробництво молока зросло на 197,86 ц, а в перерахунку на 4 \% молоко на 131,43 ц, підвищилися середньодобові надої на 1 корову відповідно +1,3; +0,89 кг, тому його використання у вигляді основного корму є цілком обґрунтованим технологічним прийомом з огляду на менеджмент годівлі дійного стада та економічні показники виробництва молока.

\section{Список використаної літератури:}

1. Білоус А. Жито - альтернативний грубий корм. Молоко і ферма № 3 (46). URL : http://milkua.info/uk/post/zitoalternativnii-grubii-korm

2. Богданов Г. О., Кандиба В. М., Ібатуллін І. І. та ін. Теорія і практика нормованої годівлі великої рогатої худоби : монографія. За ред. В. М. Кандиби, І. І. Ібатулліна, В. І. Костенка. Житомир : ПП «Рута», 2012. 860 с.

3. Борщенко В. В., Рязанцев О. В. Альтернативні види грубих кормів у годівлі високопродуктивних корів. Технологія виробництва і переробки продукції тваринництва. Зб. н. праць технологічного факультету. Випуск 8. ЖНАЕУ, 2018, С. 182 185.

4. Висоцький І. Житній сінаж-оптимальний інгредієнт раціону для корів. Agroexpert. № 3 (92). 2016. URL : https://agroexpert.ua/zitnii-sinaz-optimalnii-ingredient-racionu-dla-koriv-0/

5. Гринчук Ю. С., Шемігон О. І., Вихор М. В. Управління технологічними процесами у тваринництві: проблеми, ймовірні шляхи вирішення. Ефрективна економіка. 2021. № 1. - URL : http://www.economy.nayka.com.ua/?op=1\&z=8529 (дата звернення: 22.05.2021). DOI : 10.32702/2307-2105-2021.1.13

6. Дейв Девіс. Що ми не знали про жито. Agroexpert. № 4. 2017. URL : https://agroexpert.ua/shcho-my-ne-znaly-prozhytol

7. Ковальчук І. В., Шиян М. О. Технологія заготівлі основного корму та його якість для молочного стада ПП «Слободище» Бердичівського району Житомирської області. Технологія виробництва і переробки продукції тваринництва : науковотеоретичний збірник. ПНУ, 2020. Вип. 14. С.

8. Оврас. В. В Україні набуває популярності гібридне жито. Агропортал. URL : https://agroportal.ua/ua/news/ukraina/vukraine-priobretaet-populyarnost-gibridnaya-rozh/

9. Пьотінгер бере участь у науковому семінарі. URL : https://www.poettinger.at/uk_ua/Newsroom/Artikel/9447/

10. Сироватко К. М. Житньо-люцерновий силос у повно змішаному раціоні дійних корів. Аграрна наука та харчові технології. Вінницький національний аграрний університет. Випуск 5 (108). Том 2. 2019. С. $38-47$.

11. Driehuis, F. 2013. Silage and the safety and quality of dairy foods: a review. Agricultural and Food Science, 22 (1), pp. 16-34. URL : https://doi.org/10.23986/afsci.6699. DOI : 10.23986/afsci.6699 
12. Fedak, N., Dushara, I. 2019. Milk productivity of cows by using in rations during winter-stall period of maintenance vetchbarley silage. Scientific and Technical Bulletin of State Scientific Research Control Institute of Veterinary Medical Products and Fodder Additives and Institute of Animal Biology, 20 (2), pp. 60-66. URL : https://doi.org/10.36359/scivp.2019-20-2.08. DOI : 10.36359/scivp.2019-20-2.08.

13. Miciński, J., Pogorzelska, J., Stempel, R., Maršálek, M. 2008. Comparison of the production efficiency of cows fedtotal mixed rations (TMR) containing two types of concentrated feed, determined by the direct surplus method. Journal of Agrobiology, 25 (2): pp. 185-193. URL : http://www.zf.jcu.cz/dokumenty/dokumenty-journal-of-agrobiology/2008-number 2/Micinski\%20et\%20al.\%20(2008)\%20-\%201.pdf

14. Paterson, J. A., Belyea, R. L., Bowman, J. P., Kerley, M.S. and Williams, J. E. The Impact of Forage Quality and Supplementation Regimen on Ruminant Animal Intake and Performance. Forage Quality, Evaluation, and Utilization. URL : https://doi.org/10.2134/1994.foragequality.c2. DOI : 10.2134/1994.foragequality.c2

15. West, J. R., Ruark, M. D. and Shelley, K.B. 2020. Sustainable intensification of corn silage cropping systems with winter rye. Agronomy for Sustainable Development, Springer Verlag. 40 (2), 11 p. URL : https://doi.org/10.1007/s13593-020-00615-6. DOI : 10.1007/s13593-020-00615-6.

\section{References:}

1. Bilous, A. 2018. Zhyto - alternatyvnyi hrubyi korm. [Rye is an alternative roughage]. Moloko i ferma № 3 (46). URL : http://milkua.info/uk/post/zito-alternativnij-grubij-korm

2. Bohdanov, H. O., Kandyba, V. M., Ibatullin, I. I. ta in., 2012. Teoriia i praktyka normovanoi hodivli velykoi rohatoi khudoby : monohrafiia.[Theory and practice of normalized feeding of cattle: a monograph.]. Za red. V. M. Kandyby, I. I. Ibatullina, V. I. Kostenka. Zhytomyr, PP «Ruta»,. 860 p.

3. Borshchenko, V. V., Riazantsev, O. V., 2018. Alternatyvni vydy hrubykh kormiv u hodivli vysokoproduktyvnykh koriv. [Alternative types of roughage in the feeding of highly productive cows]. Tekhnolohiia vyrobnytstva i pererobky produktsii tvarynnytstva. Zb. n. prats tekhnolohichnoho fakultetu. Vypusk 8. ZhNAEU, pp. 182-185.

4. Vysotskyi, I. 2016. Zhytnii sinazh-optymalnyi inhrediient ratsionu dlia koriv. [Rye haylage is the optimal ingredient in the diet for cows]. Agroexpert. № 3 (92). URL : https://agroexpert.ua/zitnii-sinaz-optimalnii-ingredient-racionu-dla-koriv-0/

5. Hrynchuk, Y., Shemigon, O. and Vihor, M. 2021. Management of technological processes in animal husbandry: problems, probable ways of solution. Efektyvna ekonomika. [Online], vol. 1. URL : http://www.economy.nayka.com.ua/?op=1\&z=8529 (Accessed 22 May 2021). DOI : 10.32702/2307-2105-2021.1.13.

6. Deiv Devis. 2017. Shcho my ne znaly pro zhyto. [What we didn't know about rye]. Agroexpert. № 4. URL : https://agroexpert.ua/shcho-my-ne-znaly-pro-zhyto/

7. Kovalchuk, I. V., Shyian, M. O. 2020. Tekhnolohiia zahotivli osnovnoho kormu ta yoho yakist dlia molochnoho stada PP «Slobodyshche» Berdychivskoho raionu Zhytomyrskoi oblasti. [The technology of procurement of basic feed and its quality for the dairy herd PE «Slobodyshche» Berdychiv district of Zhytomyr region.]. Tekhnolohiia vyrobnytstva i pererobky produktsii tvarynnytstva : naukovo-teoretychnyi zbirnyk. PNU, Vyp. 14. pp.

8. Ovras, V. V. Ukraini nabuvaie populiarnosti hibrydne zhyto. [Hybrid rye is gaining popularity in Ukraine]. Ahroportal. URL : https://agroportal.ua/ua/news/ukraina/v-ukraine-priobretaet-populyarnost-gibridnaya-rozh/

9. Potinher bere uchast u naukovomu seminari. URL : https://www.poettinger.at/uk_ua/Newsroom/Artikel/9447/

10. Syrovatko, K. M. 2019. Zhytno-liutsernovyi sylos u povno zmishanomu ratsioni diinykh koriv. [Rye-alfalfa silage in a fully mixed diet of dairy cows]. Ahrarna nauka ta kharchovi tekhnolohii. Vinnytskyi natsionalnyi ahrarnyi universytet. Vypusk 5 (108). Tom 2. pp. 38-47.

11. Driehuis, F. 2013. Silage and the safety and quality of dairy foods: a review. Agricultural and Food Science, 22 (1), pp. 16-34. URL : https://doi.org/10.23986/afsci.6699. DOI : 10.23986/afsci.6699

12. Fedak, N., Dushara, I. 2019. Milk productivity of cows by using in rations during winter-stall period of maintenance vetchbarley silage. Scientific and Technical Bulletin of State Scientific Research Control Institute of Veterinary Medical Products and Fodder Additives and Institute of Animal Biology, 20 (2), pp. 60-66. URL : https://doi.org/10.36359/scivp.2019-20-2.08.

DOI : 10.36359/scivp.2019-20-2.08.

13. Miciński, J., Pogorzelska, J., Stempel, R., Maršálek, M. 2008. Comparison of the production efficiency of cows fedtotal mixed rations (TMR) containing two types of concentrated feed, determined by the direct surplus method. Journal of Agrobiology, 25 (2): $\quad$ pp. 185-193. URL : http://www.zf.jcu.cz/dokumenty/dokumenty-journal-of-agrobiology/2008-number 2/Micinski\%20et\%20al.\%20(2008)\%20-\%201.pdf

14. Paterson, J. A., Belyea, R. L., Bowman, J. P., Kerley, M.S. and Williams, J. E. The Impact of Forage Quality and Supplementation Regimen on Ruminant Animal Intake and Performance. Forage Quality, Evaluation, and Utilization. URL : https://doi.org/10.2134/1994.foragequality.c2. DOI : 10.2134/1994.foragequality.c2

15. West, J. R., Ruark, M. D. and Shelley, K.B. 2020. Sustainable intensification of corn silage cropping systems with winter rye. Agronomy for Sustainable Development, Springer Verlag. 40 (2), 11 p. URL : https://doi.org/10.1007/s13593-020-00615-6. DOI : 10.1007/s13593-020-00615-6. 
Shevchuk Oleg Antonovuch, Director PP «Slobodishche» (Berdychiv, Ukraine)

Kovalchuk Igor Vasulevich, PhD of Agricultural Sciences, Docent Polissya National University (Zhytomyr, Ukraine)

Shiyan Mukola Oleksandrovich, Animal technician PP «Slobodishche» (Berdychiv Ukraine)

Kovalchuk Iryna Igorevna, PhD of Veterinary Sciences, Senior Lecturer Polissya National University (Zhytomyr, Ukraine)

Basik feed from hybrid winter rye: harvesting, quality and usage in feeding of dairy cows

The key factor in reducing milk productivity of cows, duration of their economic use, reproductive function is the direct influence of a number of nutritional factors. That is why in recent years, the management of dairy farms directs its work on valuation of the quality characteristics of main feed (hay, silage, haylage) to feed cattle. It should be noted that today you can trace a tendency to use in practice feed, silage in particular, from cereals. Production of such feed from winter rye is promising, due to its unpretentiousness to agricultural machinery (frost resistance, early sowing, intensive development), high yields, resistance to fungal diseases. Furthermore, rye silage features by a high content of nutrients. That is why the main task of our research was to study the harvesting system and rate the effectiveness of the use of silage from winter rye in the feeding of high-yielding dairy cows in the conditions of PP "Slobodyshche" Berdychiv district of Zhytomyr region. The main goal was to study the influence of a common mixed diet of different composition on cows milk productivity. We have presented a technological scheme from agricultural techniques of hybrid winter rye, harvesting and preparation of silage. It is established that the main quality indicators of silage from hybrid winter rye meet the requirements of 1 class(according to DSTU 4782: 2007). 520 heads of Holstein and Jersey cows were involved in the production experiment. The duration of the experiment is 60 day divided into two periods: 1 st - usage of corn silage as the main feed (previous year of harvest), 2nd - use of corn silage and early silage from winter rye. It was studied out that feeding cows silage from winter rye - as the main feed, together with corn silage - milk production increased by 197.86 quintals, and with recalculation of $4 \%$ milk, by 131.43 quintals, increased the average daily milk yield per cow $(+1.3 ;+0.89 \mathrm{~kg})$, accordingly, that is why the use of winter rye as a basic feed is quite reasonable, given the management of feeding the dairy herd and economic indexes of milk production.

Key words: winter rye, technological procedures, silage, feeding of cows, primary feed, ketosis, milk yield.

Дата надходження до редакції: 24.05.2021 p. 